DOI: 10.20472/IAC.2018.935.010

\author{
AZIME ASLI BILGIN \\ Cukurova University Faculty of Law, Turkey
}

\title{
THE STATUS OF IRREGULAR MIGRANTS AT SEA: THE PRINCIPLE OF NON-REFOULEMENT V. PUSH-BACK OPERATIONS
}

\begin{abstract}
:
Since the conflict began in 2011, an estimated 5 million people have fled Syria by land and sea in order to survive. The Aegean sea from Turkey to Greece has become one of the popular and deadly routes for asylum-seekers and migrants to reach Europe since then. In 2015, while more than 851.000 asylum seekers entered to Greece via the Aegean sea route. The number of the irregular migrants coming to the European Union has begun to threat the area of freedom, security and justice which is established to enable its citizens to exercise their free movement rights.

The principle of non-refoulement which prohibits the expulsion, deportation, or return of a refugee to a state where refugee's life would be in danger is accepted by most States, including the EU in accordance with the protection of human rights.

At this point a dilemma has appeared for the EU. While preventing the entrance of the irregular migrants to the area of freedom, security and justice via push-back operations in Aegean on the one hand, the breach of non-refoulement principle occurs on the other.

Because of the reasons above, this paper aims to examine the breach of non-refoulement principle via push-back operations in the Aegean Sea and determine the responsibility of States stemmed from the principle in the light of international law.
\end{abstract}

\section{Keywords:}

The principle of non-refoulement, refugees, irregular migration, human rights,

JEL Classification: F22, K33 